CORRECTION

\title{
Correction to: Grazing weakens competitive interactions between active methanotrophs and nitrifiers modulating greenhouse-gas emissions in grassland soils
}

Hong Pan, Haojie Feng, Yaowei Liu, Chun-Yu Lai, Yuping Zhuge, Qichun Zhang, Caixian Tang, Hongjie Di, Zhongjun Jia (D, Cécile Gubry-Rangin (iD, Yong Li (iD) and Jianming Xu iD

(c) The Author(s) 2022

ISME Communications; https://doi.org/10.1038/s43705-022-00090-y

Correction to: ISME Communications https://doi.org/10.1038/ s43705-021-00068-2, published online 9 December 2021

The " $\mathrm{CH}_{4}$ emissions" should be " $\mathrm{CH}_{4}$ uptake" in the sentence of "Grazing significantly decreases $\mathrm{CH}_{4}$ emissions while it increases $\mathrm{N}_{2} \mathrm{O}$ emissions basing on 14-month in situ measurement"

The correct sentence should be read:

Grazing significantly decreases $\mathrm{CH}_{4}$ uptake while it increases $\mathrm{N}_{2} \mathrm{O}$ emissions basing on 14-month in situ measurement

The original article has been revised.

\begin{abstract}
Open Access This article is licensed under a Creative Commons Attribution 4.0 International License, which permits use, sharing, adaptation, distribution and reproduction in any medium or format, as long as you give appropriate credit to the original author(s) and the source, provide a link to the Creative Commons license, and indicate if changes were made. The images or other third party material in this article are included in the article's Creative Commons license, unless indicated otherwise in a credit line to the material. If material is not included in the article's Creative Commons license and your intended use is not permitted by statutory regulation or exceeds the permitted use, you will need to obtain permission directly from the copyright holder. To view a copy of this license, visit http://creativecommons. org/licenses/by/4.0/.
\end{abstract}

(c) The Author(s) 2022 